\title{
Temperature control of bacterioplankton growth in a temperate large lake
}

\author{
Meinhard Simon*, Christine Wünsch \\ Limnological Institute, University of Constance, PO Box 5560, D-78457 Konstanz, Germany
}

\begin{abstract}
In order to examine the significance of temperature in controlling growth of bacterioplankton in a large lake with a pronounced pelagic zone we performed 12 temperature shift-up experiments year-round in mesotrophic Lake Constance, Germany, with samples from 1, 6, 10 or 20 and $50 \mathrm{~m}$ depth. We measured incorporation of ${ }^{14} \mathrm{C}$-leucine (Leu) and ${ }^{3} \mathrm{H}$-thymidine (TdR) at 5, 10, 15, 20 and $25^{\circ} \mathrm{C}$ including the in situ temperature $\pm 2^{\circ} \mathrm{C}$. The results show that during most of the year bacteria at 1 and $6 \mathrm{~m}$ were well adapted to the ambient temperature, ranging between 4 and $23^{\circ} \mathrm{C}$, because in situ and optimum growth temperatures agreed within 1 to $5^{\circ} \mathrm{C}$. At 20 and $50 \mathrm{~m}$, in situ and optimum growth temperatures usually diverged by more than $5^{\circ} \mathrm{C}$, and often by more than $10^{\circ} \mathrm{C}$, indicating that bacterial growth at these depths was clearly limited by temperature. Hence, in the upper water column, temperature controlled bacterial growth by selecting for a well-temperature-adapted community whereas in the lower part of the water column temperature directly controlled bacterial growth. In several experiments we observed 2 temperature optima. We interpret this observation as an indication of the existence of 2 different subpopulations with different temperature preferences. $Q_{10}$ values of Leu incorporation and $T d R$ incorporation, ranging from 1.4 to 42.5 , exhibited systematic differences. At 1,6 and $10 \mathrm{~m}, Q_{10}$ of Leu was higher than that of TdR except in 3 cases, whereas at 20 and $50 \mathrm{~m} Q_{10}$ of TdR was higher than that of Leu except in 3 cases. This observation suggests that protein synthesis (Leu) and DNA replication (TdR) are controlled differently by temperature in differently adapted bacterial communities. In order to test the hypothesis that utilization of the most important substrates is optimized at the optimum growth temperature we carried out 5 additional experiments in which we measured uptake and respiration of dissolved free amino acids and monosaccharides. In 3 experiments we found that the fraction of amino acids respired had a distinct minimum at the optimum growth temperature whereas respiration of monosaccharides had such a minimum only in 1 experiment. The experiments gave no indication of enhanced respiration percentages at minimum growth temperatures.
\end{abstract}

KEY WORDS: Temperature - Bacterial production - Amino acid uptake Monosaccharide uptake . Respiration - Large lake

\section{INTRODUCTION}

The growth of heterotrophic bacteria in natural environments usually is limited by some factor like the resource which exhibits the greatest discrepancy between requirements and availability. Depending on the trophic state and seasonal situation of the given environment, organic carbon or nitrogen, ammonium or inorganic phosphate most often have been identi-

\footnotetext{
- Present address: Institute for Chemistry and Biology of the Marine Environment (ICBM), University of Oldenburg, PO Box 2503, D-26111 Oldenburg, Germany.

E-mail: m.simon@icbm.uni-oldenburg.de
}

fied as limiting bacterioplankton growth (Kirchman 1990, Coveney \& Wetzel 1992, Morris \& Lewis 1992 , Zweifel et al. 1993, Schweitzer \& Simon 1995). Besides resources, temperature has been found to limit growth of planktonic bacteria, in particular at relatively low temperature. Positive correlations between temperature and bacterioplankton growth parameters below a certain temperature have been found in estuarine environments, the subtropical convergence of the Atlantic and in lakes (Morris \& Lewis 1992, Hoch \& Kirchman 1993, Shiah \& Ducklow 1994a, Coveney \& Wetzel 1995, Tibbles 1997). Above these temperatures, abundance and growth were independent of temperature, implying that other factors like resources con- 
trolled bacterioplankton growth. In a cross-system overview of freshwater and marine environments White et al. (1991) also found a positive correlation between temperature and the bacterioplankton specific growth rate. On the other hand, Rivkin et al. (1996) in a more recent cross-system overview of marine environments did not find a significant positive correlation between temperature and bacterioplankton specific growth rate.

The studies mentioned indicate that there is a general control of bacterioplankton growth by temperature, directly or indirectly. There is, however, evidence based on temperature shift-up and shift-down experiments that the bacterioplankton communities often are not well adapted to the ambient temperatures, in particular in colder environments (Lovell \& Konopka 1985, Li \& Dickie 1987, Autio 1992, Kirchman et al. 1993, Shiah \& Ducklow 1994b, 1997, Felip et al. 1996, Pakulski et al. 1996).

It is important to examine the temperature adaptation of planktonic bacteria because of the implications for the cycling of dissolved organic matter (DOM) and the global carbon cycle. Wiebe et al. (1992, 1993) examined the growth rates of bacterial isolates as a function of temperature and substrate concentration and found that the concentrations needed to sustain a certain growth rate increased with decreasing temperature. Hence, we hypothesize that at temperatures far below the optimum growth temperature, bacteria use relatively more of the substrates for energy requirements, which means that the growth efficiency at such low temperatures would be reduced compared to growth close to the optimum temperature. A consequence of this would also be that the amount of DOM recycled into the food web via the microbial loop or respired to $\mathrm{CO}_{2}$ depends on how well bacteria are adapted to the ambient temperature. It would be interesting to examine whether similar relationships also hold true for temperatures exceeding the optimum. This hypothesis also would imply that bacterioplankton communities strive to adapt closely to the ambient temperature, if the conditions allow, in order to optimize utilization of substrates for biosynthetic processes. Hence, it is interesting to examine how the dominant substrates, amino acids and carbohydrates (Jørgensen et al. 1993, Rosenstock \& Simon 1993, Kroer et al. 1994, Middelboe et al. 1995, Hanisch et al. 1996, Rich et al. 1996, Simon et al. 1998) are metabolized with respect to biosynthesis and energy requirements. Uptake and respiration of these substrates should reflect most comprehensively how bacteria obtain their biosynthetic and energetic requirements.

In order to examine the role of temperature in the bacterial cycling of DOM we studied the adaptation of planktonic bacteria to the ambient temperature throughout the year in Lake Constance, Germany, a large mesotrophic lake. By using the dual-label approach we simultaneously measured rates of thymidine-based bacterial cell multiplication (BCM) and of leucine-based biomass production (BPP-C) in the epi-, meta- and hypolimnion at 5,10,15,20 and $25^{\circ} \mathrm{C}$. In addition we measured respiration of dissolved free amino acids and monosaccharides to test the hypothesis that respiration is minimized at the optimal growth temperature.

\section{MATERIAL AND METHODS}

The study was carried out between May 1995 and March 1997 at the center and deepest point of Lake Überlingen, the northwestern arm of mesotrophic and warm-monomictic Lake Constance, Germany. The maximum depth of Lake Constance is $254 \mathrm{~m}$ whereas that of Lake Überlingen reaches $147 \mathrm{~m}$. The structure and microbial dynamics of the plankton community in Lake Constance have been studied extensively during the last decade (e.g. Gaedke \& Straile 1994, Simon et al. 1998, Weisse \& Müller 1998). Samples were collected with a clean van Dohrn bottle at 1, 6, 10 or 20 and $50 \mathrm{~m}$. From May until 1 August 1995 the depth of $10 \mathrm{~m}$ was sampled as the layer of the thermocline and thereafter a sample from $20 \mathrm{~m}$ was taken due to the deepening of the thermocline. Subsamples were withdrawn into clean $1 \mathrm{l}$ polyethylene bottles and kept in a cooling box until further processing in the lab. Experiments started within $2 \mathrm{~h}$ of sampling. In situ temperatures were continuously recorded at the sampling station with thermistor chains. Calculated $3 \mathrm{~h}$ means are given in Fig. 1

Twelve experiments were carried out in which the growth of planktonic bacteria as a function of temperature was examined at the 4 depths indicated. In the first experiment incubation temperatures were 5,10 , 18 and $23^{\circ} \mathrm{C}$ and in the others $5,10,15,20$ and $25^{\circ} \mathrm{C}$. These temperatures included the ambient temperature $\pm 2^{\circ} \mathrm{C}$. The bacterioplankton growth in samples from $50 \mathrm{~m}$ was examined only in a range from 5 to $20^{\circ} \mathrm{C}$. Additional experiments with surface samples (12 and 19 September 1996) and samples from $1 \mathrm{~m}$ (3 Derember 1996, 14 January 1997) and $10 \mathrm{~m}$ (25 March 1997) were performed in which uptake and respiration of dissolved free amino acids and monosaccharides in this temperature range was measured as well.

Rates of biomass production and cell multiplication of heterotrophic bacterioplankton were determined by the incorporation of ${ }^{14} \mathrm{C}$-leucine (Leu; Kirchman et al. 1985. Simon \& Azam 1989) and ${ }^{3} \mathrm{H}$-thymidine (TdR; Fuhrman \& Azam 1980) using the dual-label approach (Chin-Leo \& Kirchman 1988). Subsamples of $5 \mathrm{ml}$ were 
Fig. 1. In situ temperatures at 1,6, 10, 20 and $50 \mathrm{~m}$ in Lake Constance between April 1995 and April 1996. Arrows indicate when temperature shift-up experiments were carried out

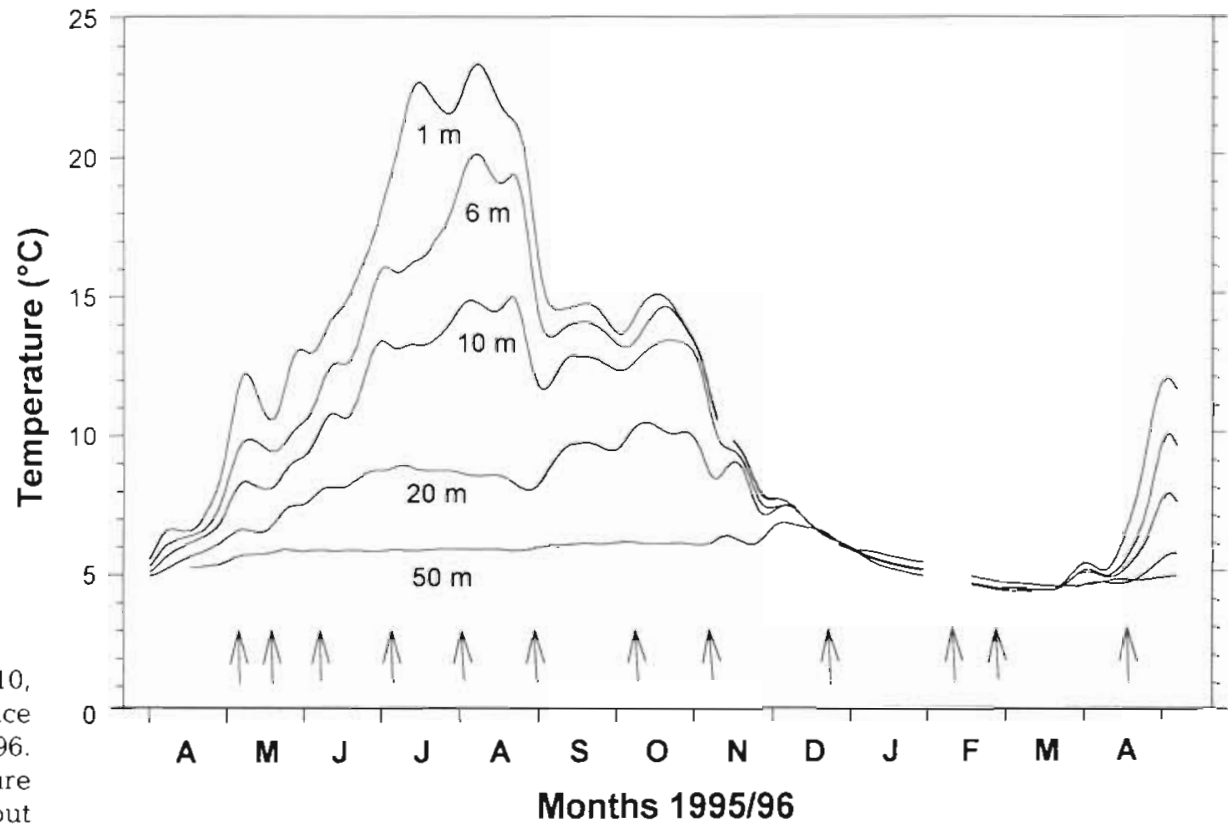

withdrawn into clean polystyrene test tubes. Triplicates and a Formalin-killed control were labelled with ${ }^{14} \mathrm{C}$-Leu $\left(11.5 \mathrm{GBq} \mathrm{mmol}^{-1}\right.$, Amersham) and TdR (3 TBq $\mathrm{mmol}^{-3}$, Amersham, diluted 1:5 with nonlabelled $\mathrm{TdR}$ ) at a final concentration of $30 \mathrm{nM}$ each. Experiments in various seasons confirmed that this concentration maximized incorporation of Leu and $\mathrm{TdR}$. Incubation at the temperatures indicated above in the dark was stopped after 90 min by adding Formalin ( $2 \%$ final concentration). Samples were not preadjusted to these temperatures because of the small sample volume. Depending on the ambient and incubation temperature the samples adjusted to the incubation temperature within 5 to $10 \mathrm{~min}$. After fixation, samples were filtered onto $0.45 \mu \mathrm{m}$ nitrocellulose filters (Sartorius), rinsed with ice-cold particle-free lake water and extracted with ice-cold 5\% trichloroacetic acid (TCA) for $5 \mathrm{~min}$. After rinsing the extracted filters twice with ice-cold 5\% TCA, the filters were dissolved with ethylacetate and radioassayed by liquid scintillation counting. Bacterial production (BPP-C, $\mathrm{g} \mathrm{Cl}^{-1} \mathrm{~h}^{-1}$ ) was calculated from Leu incorporation rates by using a conversion factor of $2.63 \mathrm{~kg} \mathrm{C}$ (mol Leu) ${ }^{-1}$ (Simon \& Rosenstock 1992). This conversion factor includes a 2 -fold intracellular isotope dilution of Leu and a protein:C ratio of 0.86 . To convert $T d R$ incorporation into rates of bacterial cell multiplication (BCM) a conversion factor of $2 \times 10^{18}$ cells (mol TdR)-1 (Simon \& Rosenstock 1992) was used.

Uptake rates of a mixture of $16{ }^{14} \mathrm{C}$-amino acids (Amersham, mean specific activity $1.97 \mathrm{GBq}$ milliatom ${ }^{-1} \mathrm{C}$ ) and an equal molar mixture of ${ }^{14} \mathrm{C}$-monosac- charides (glucose, galactose, fructose, mannose, Nacetyl-glucosamin, mean specific activity $10.2 \mathrm{GBq}$ $\mathrm{mmol}^{-1}$, Amersham) were measured basically in the same way as described for measurements of Leu and TdR incorporation (see above) but separate incubations were used for each label. Final concentrations of total amino acids and monosaccharides added were $5 \mathrm{nM}$, respectively. After stopping the incubation, samples were not extracted by ice-cold TCA but filtered directly onto $0.45 \mu \mathrm{m}$ nitrocellulose filters and rinsed with particle-free lake water. Respiration of ${ }^{14} \mathrm{C}$-amino acids and ${ }^{14} \mathrm{C}$-monosaccharides was measured according to Hobbie \& Crawford (1969) in $50 \mathrm{ml}$ samples in $100 \mathrm{ml}$ Erlenmeyer flasks with screw caps. These samples were preadjusted to the incubation temperature for $30 \mathrm{~min}$. Triplicates and a Formalin-killed control were labelled with $5 \mathrm{nM}$ (final concentration) of the respective radiotracer and incubated for $90 \mathrm{~min}$. After stopping the incubation the evolved ${ }^{14} \mathrm{CO}_{2}$ was trapped in phenethylamine-soaked filterpapers (Whatman no. 1) fixed in a wire hook inside the neck of the Erlenmeyer flask. Samples were acidified by adding $250 \mu \mathrm{l}$ $0.1 \mathrm{~N} \mathrm{HCl}$ with a syringe through the silicon septum of the screw cap and shaken overnight such that $>98 \%$ of the ${ }^{14} \mathrm{CO}_{2}$ produced was trapped in the filter paper. The filter papers were radioassayed by liquid scintillation counting.

Gross turnover rates of dissolved free amino acids and monosaccharides were calculated as the sum of the respective uptake and respiration rates. The relative proportions of respired substrates were calculated as the ratio of respiration rates/gross turnover rates. 


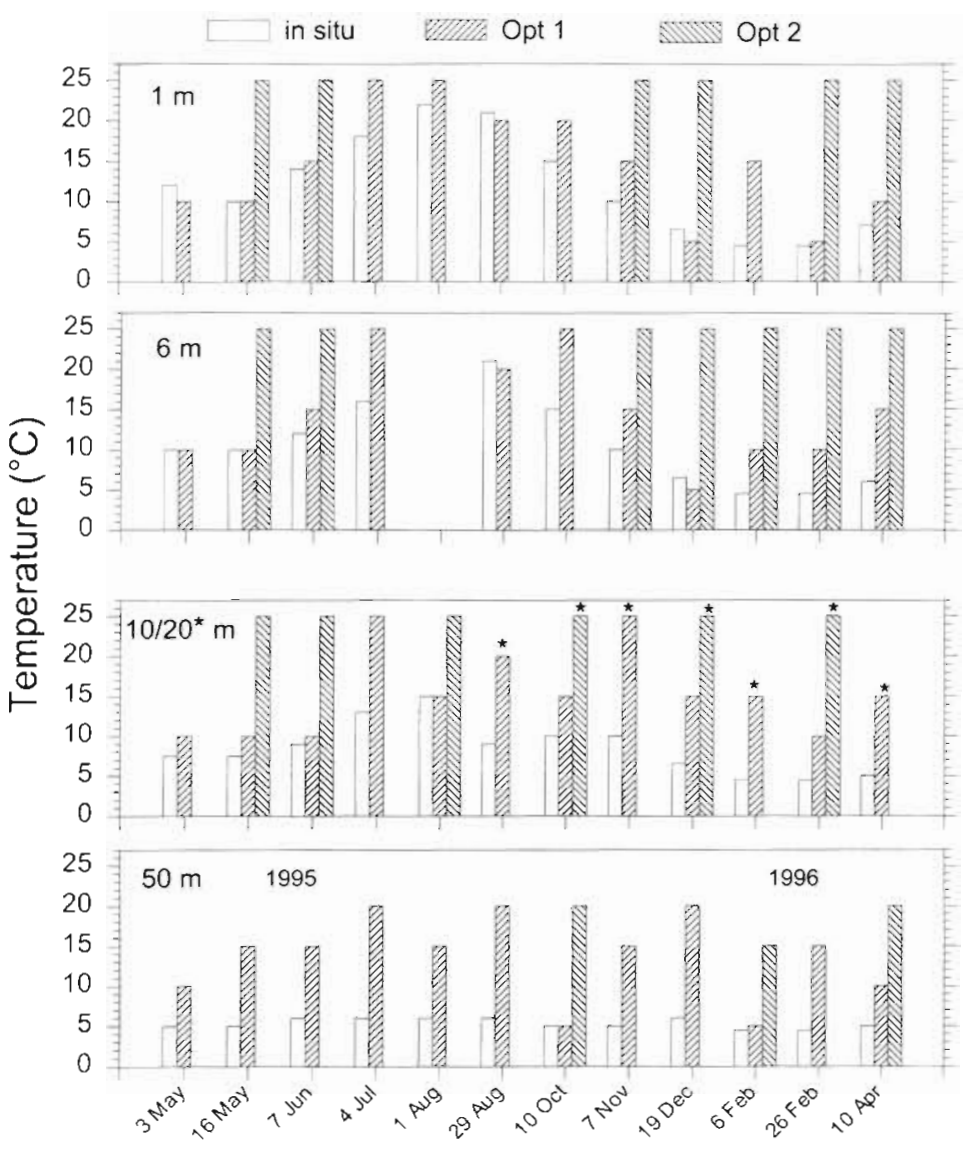

Fig. 2. Temperatures in situ and at optimum growth of bacterioplankton determined as rates of protein-based bacterial carbon production (BPP-C) in Lake Constance. (*) Experiments in which samples were taken at $20 \mathrm{~m}$
The temperature optimum was defined as the lowest temperature tested which yielded rates of bacterial production not statistically different from the highest rates. Responses of BPP-C and BCM to increasing temperatures were calculated on the basis of their respective $Q_{10}$ values calculated as $Q_{10}=\left(K_{1} / K_{2}\right)^{10 /\left(t_{1}-t_{2}\right)}$ (Sherr \& Sherr 1996). $K_{1}$ and $K_{2}$ are bacterial production rates at temperatures $t_{1}$ and $t_{2}\left(\right.$ in ${ }^{\circ} \mathrm{C}$ ), where $t_{1}>t_{2}, t_{2}$ and $t_{1}$ covered the entire temperature range from $5^{\circ} \mathrm{C}$ to the first optimum or that of increasing temperature below the second, higher optimum.

\section{RESULTS}

At 1,6 and $10 \mathrm{~m}$ the temperature increased fairly continuously between April and early August such that highest temperatures of 23,20 and $15^{\circ} \mathrm{C}$, respectively, were reached (Fig. 1). At the end of August there was a sharp drop in temperature to 12 to $15^{\circ} \mathrm{C}$ at these depths due to a strong storm. At $20 \mathrm{~m}$ the temperature remained below $9^{\circ} \mathrm{C}$ until early September and slightly increased further until October whereas at $50 \mathrm{~m} 7^{\circ} \mathrm{C}$ was not exceeded throughout the year.

The response of bacterioplankton growth to the different temperature regimes exhibited 1 or 2 optima at varying temperatures and thus indicated pronounced differences in the adaptation patterns depending on the seasonal situation and depth. At 1,6 and $10 / 20 \mathrm{~m}$ the second optimum was always at $25^{\circ} \mathrm{C}$ and that at $50 \mathrm{~m}$ in 2 cases at $20^{\circ} \mathrm{C}$ (Fig. 2). Because temperatures higher than $25^{\circ} \mathrm{C}$ at 1,6 and $10 / 20 \mathrm{~m}$ and than $20^{\circ} \mathrm{C}$ at $50 \mathrm{~m}$ were not tested we do not know whether these temperatures, in fact, were the optimum or whether it was even higher. For reasons of conformity, however, we keep the expression 'optimum temperature'. Because in most cases optimum temperatures for BPP-C and BCM were similar, only the temperature patterns of BPP-C are shown (but see below for differences of $\mathrm{BCM}$ ). In the vast majority of the experiments at 1,6 and $10 \mathrm{~m}$ covering temperatures between 5 and $25^{\circ} \mathrm{C}$, in situ temperatures and optimum temperatures, or when 2 optima occurred the lower one, ranged within $5^{\circ} \mathrm{C}$. At 20 and $50 \mathrm{~m}$ rates of BPP-C and BCM at in situ and optimum temperatures more often diverged by $>5^{\circ} \mathrm{C}$, indicating that at these depths the bacterioplankton was less well adapted to the ambient temperatures. However, at $50 \mathrm{~m}$ at certain times the in situ temperature and

Table 1. Linear regression analysis of in situ and optimum temperature $(T)$ versus bacterioplankton growth at in situ and optimum temperatures $(p<0.01)$. Given is $r^{2}$ of temperature versus both rates of protein-based bacterial carbon production (BPP-C) and bacterial cell multiplication (BCM)

\begin{tabular}{|c|c|c|c|c|}
\hline Depth & $x$-value & $y$-value & $r^{2}(B P P-C)$ & $r^{2}(B C M)$ \\
\hline \multirow[t]{4}{*}{$1 \mathrm{~m}$} & $T_{\text {in situ }}$ & Growth $_{\text {in situ }}$ & 0.59 & 0.64 \\
\hline & $T_{\mathrm{opt}}$ & Growth $_{\text {in situ }}$ & 0.17 & 0.18 \\
\hline & $T_{\text {in situ }}$ & Growth & 0.60 & 0.58 \\
\hline & $T_{\mathrm{opt}}$ & Growth $_{\text {opt }}$ & 0.25 & 0.18 \\
\hline \multirow[t]{4}{*}{$6 \mathrm{~m}$} & $T_{\text {in situ }}$ & Growth $_{\text {In situ }}$ & 0.26 & 0.35 \\
\hline & $T_{\text {opt }}$ & Growth $_{\text {in situ }}$ & 0.04 & 0.05 \\
\hline & $T_{\text {in situ }}$ & Growth $_{o p t}$ & 0.30 & 0.35 \\
\hline & $T_{o p t}$ & Growth $_{\mathrm{opt}}$ & 0.14 & 0.15 \\
\hline \multirow[t]{4}{*}{$10 / 20 \mathrm{~m}$} & $T_{i n \text { situ }}$ & Growth $_{\text {in situ }}$ & 0.32 & 0.65 \\
\hline & $T_{\text {opt }}$ & Growth $_{\text {in situs }}$ & 0 & 0.23 \\
\hline & $T_{i n \text { situ }}$ & Growth $_{\text {opt }}$ & 0.60 & 0.47 \\
\hline & $T_{\mathrm{opl}}$ & Growth & 0.11 & 0.15 \\
\hline
\end{tabular}


lower optimum of rates of BPP-C or BCM or of both parameters were similar, such as on 10 October and 6 February (Fig. 2), indicating that at least a subpopulation of the ambient bacterioplankton was well temperatureadapted. At several dates and depths the temperature optima of BPP-C and BCM were different such as on 3 and 16 May and on 6 and 26 February at a few depths. At $50 \mathrm{~m}$ the optimum temperature of BCM rates did not exceed $15^{\circ} \mathrm{C}$ except on 4 July and 10 April. In contrast, rates of BPP-C exhibited optima at $20^{\circ} \mathrm{C}$ in 5 of 12 experiments (Fig. 2).

Examples of the temperature shift-up patterns are given in Fig. 3. The different patterns on 3 and 16 May indicate the pronounced change in the temperature adaptation of bacterioplankton growth throughout the water column within 2 wk. On 3 May there was only 1 optimum at $10^{\circ} \mathrm{C}$ from 1 to $10 \mathrm{~m}$ and even an inhibition of bacterial growth above $20^{\circ} \mathrm{C}$ at 1 and $6 \mathrm{~m}$. Two weeks later, however, a second optimum at $25^{\circ} \mathrm{C}$ occurred even though the in situ temperatures remained fairly similar (Figs. $1 \& 3$ ). On 29 August after a strong storm the in situ and optimum temperatures of bacterial growth at 1 and $6 \mathrm{~m}$ were $20^{\circ} \mathrm{C}$ even though before this storm in early August the optimum temperature had been $25^{\circ} \mathrm{C}$ (Fig. 2). On 26 February the temperature adaptation exhibited biphasic patterns at 1, 6 and $20 \mathrm{~m}$ with lower optima at 5 and $10^{\circ} \mathrm{C}$.

The effect of temperature adaptation on bacterioplankton growth for cycling of organic matter and its transfer into the food web becomes evident from the comparison of rates of BPP-C and BCM at in situ and optimum temperatures (Fig. 4). During the growing season from May until October BPP-C rates at 1 and $6 \mathrm{~m}$ varied not more than 1.5-fold except on 10 October at $6 \mathrm{~m}$. In most cases rates at both temperatures agreed within $25 \%$. Interestingly, the highest rates of BPP-C and $\mathrm{BCM}$ at in situ temperature occurred on 3 May at 1 and $6 \mathrm{~m}$ at the peak of the phytoplankton spring bloom and at in situ temperatures of 10 to $12^{\circ} \mathrm{C}$. On this day the bacterioplankton was well adapted to the ambient temperature (Figs. $2 \& 3$ ). During the growing season at $10 \mathrm{~m}$ and below and throughout the water column from November until April rates at in situ and optimum temperatures often differed by more than 2 -fold.

A linear regression analysis demonstrated that rates of BPP-C and BCM at 1, 6 and $10 / 20 \mathrm{~m}$ at the in situ as well as at the optimum temperature were significantly correlated to the in situ temperature but such a corre-
3 May 1995

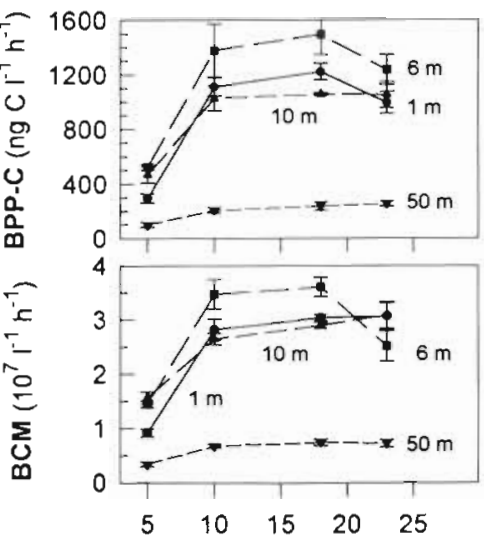

16 May 1995
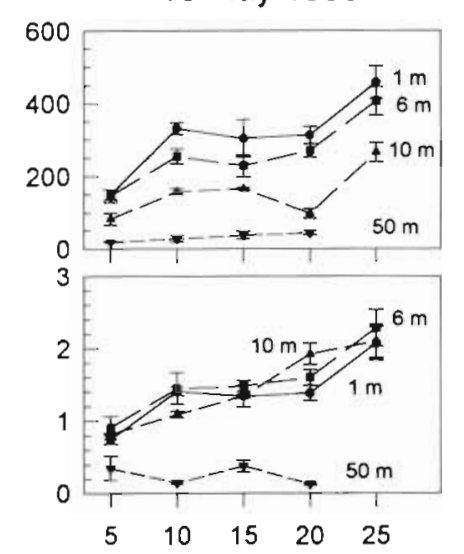

Temperature $\left({ }^{\circ} \mathrm{C}\right)$

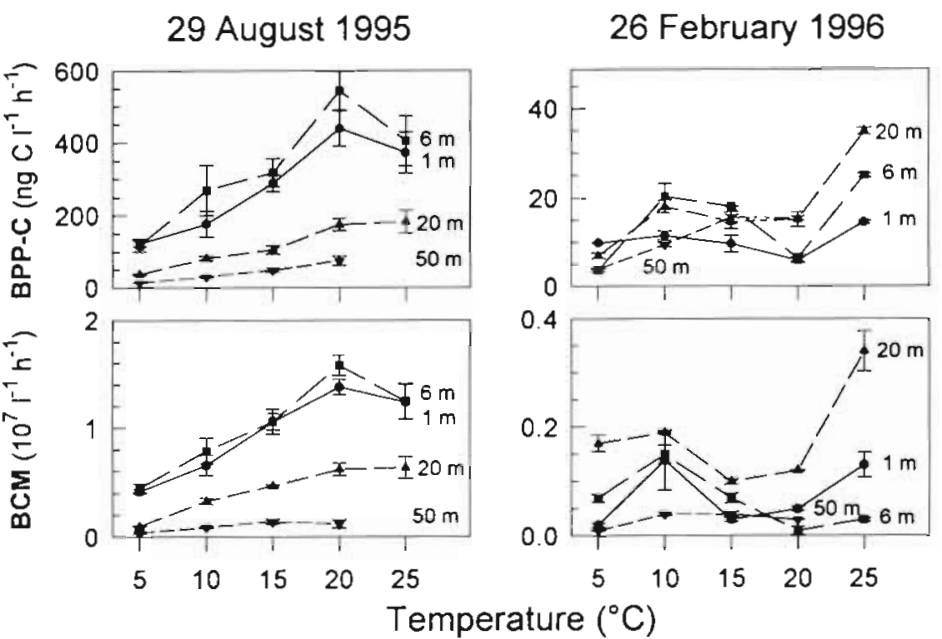

Fig. 3. Rates of protein-based bacterial carbon production (BPP-C) and bacterial cell multiplication $(\mathrm{BCM}) \pm$ standard deviation in the temperature shift-up experiments on 3 May, 16 May, 29 August and 26 February in Lake Constance

lation did not exist between these bacterial growth parameters and the optimum temperature (Table 1). At $1 \mathrm{~m}$ the in situ temperature explained $60 \%$ of the variability in BPP-C and BCM at in situ and optimum temperature. At $10 / 20 \mathrm{~m}$ the in situ temperature also explained around $60 \%$ of the variability of BCM at in situ temperature and of the variability of BPP-C at optimum temperature. At $6 \mathrm{~m}$ this correlation was much weaker than at 1 and $10 / 20 \mathrm{~m}$ as shown by an $\mathrm{r}^{2}$ of only $50 \%$ of that at the other depths.

The direct effect of temperature on BPP-C and BCM was determined from the $Q_{10}$ values. For BPP-C, $Q_{10}$ values ranged between 1.4 and 30.4 and for $B C M$ between 1.4 and 42.5 . Eighty-six percent of the $Q_{10}$ values for BPP-C and $81 \%$ of those for BCM ranged between 1.5 and 6.0 . The temperature ranges for both parameters sometimes varied but in 42 cases they were 

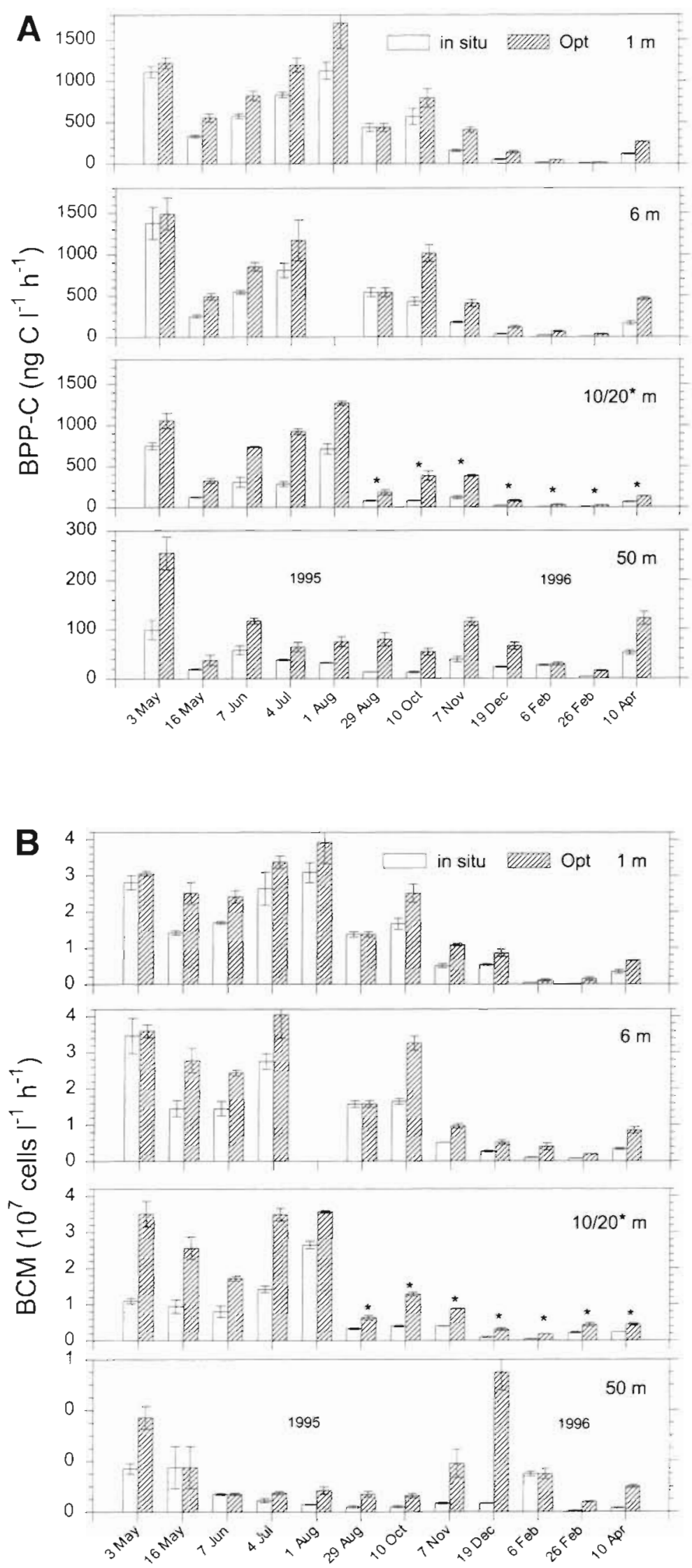

similar (Fig. 5). At 1,6 and $10 \mathrm{~m} Q_{10}$ values of BPP-C rates were higher than those of $B C M$ rates except in 3 cases (Fig. 6). In contrast, at 20 and $50 \mathrm{~m} Q_{10}$ values of BCM rates were at least as high but often higher than those of BPP-C except in 3 cases (Fig. 6).

Uptake and respiration of amino acids and monosaccharides also exhibited quite different responses to the varying thermal regime. In situ temperatures at the respective depth were $17^{\circ} \mathrm{C}$ on 12 and 19 September, $7^{\circ} \mathrm{C}$ on 3 December and $4^{\circ} \mathrm{C}$ on 14 January and 25 March. In September, rates of bacterial growth, gross uptake of amino acids and monosaccharides were much higher than on the other dates during winter. Generally, the temperature response of amino acid and monosaccharide uptake followed that of $\mathrm{BPP}-\mathrm{C}$ and $\mathrm{BCM}$, with 1 or 2 optima ranging from 15 to $25^{\circ} \mathrm{C}$ even though some differences occurred with respect to the optimum temperature, such as on 19 September and 14 January.

Respiration percentages of amino acids and monosaccharides also exhibited pronounced differences to increasing temperatures. The data, however, did not exhibit a consistent trend with amino acid and monosaccharide uptake and bacterial growth. On 12 September the percentage of amino acids respired was inversely related to increasing temperature and thus to bacterial growth and amino acid gross uptake (Fig. 7). The relative respiration of monosaccharides was also inversely related to temperature between 10 and $20^{\circ} \mathrm{C}$ but increased at $25^{\circ} \mathrm{C}$ at the maximum of bacterial growth. On 19 September the percentage of amino acids respired was positively correlated to rates of BPP-C $\left(\mathrm{r}^{2}=0.96, \mathrm{p}<0.01\right)$ and BCM $\left(\mathrm{r}^{2}=\right.$ $0.86, p<0.01$ ) whereas that of monosaccharides showed only little differences with temperature. On 3 December the percentage of amino acids respired was fairly constant over the entire temperature range whereas that of monosaccharides was around $20 \%$ between 5 and $10^{\circ} \mathrm{C}$ and around $50 \%$ at $15^{\circ} \mathrm{C}$ and above (Fig. 8). On 14 January the relative respiration of both amino acids and mono-

Fig. 4. Rates of (A) protein-based bacterial carbon production (BBP-C) and (B) bacterial cell multiplication $(B C M) \pm$ standard deviation at in situ and optimum temperatures in Lake Constance. ( $*$ ) Experiments in which samples were taken at $20 \mathrm{~m}$ 


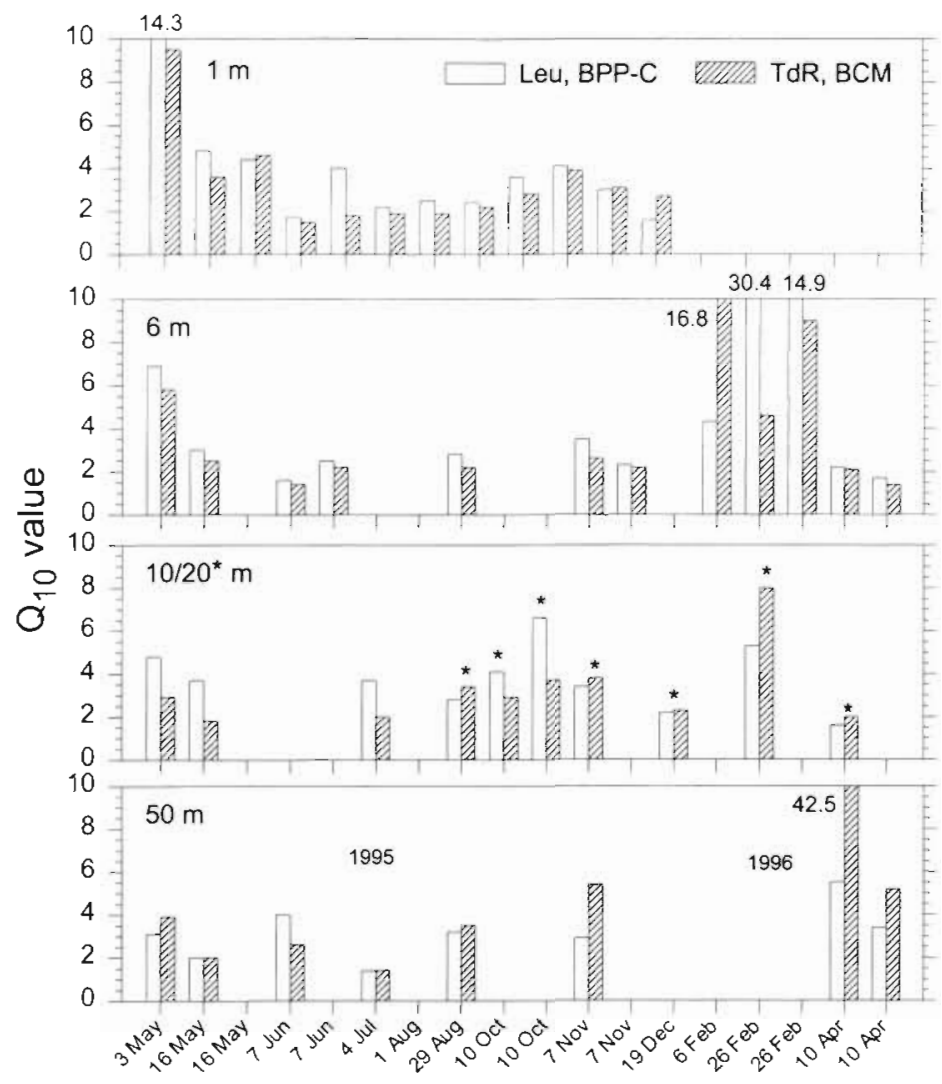

Fig. 5. $Q_{10}$ of rates of protein-based bacterial carbon production (BPP-C) and bacterial cell multiplication (BCM) in Lake Constance. Only data from experiments in which the ranges for calculating $Q_{10}$ values of BPP-C and BCM matched are shown. (*) Experiments in which samples were taken at $20 \mathrm{~m}$

saccharides showed a distinct peak at $10^{\circ} \mathrm{C}$ at low gross uptake rates (Fig. 8). On 25 March the relative respiration of both amino acids and monosaccharides was highest at $25^{\circ} \mathrm{C}$, the temperature of the higher growth optimum, whereas it was lowest at $15^{\circ} \mathrm{C}$, that of the lower optimum.

The results gave no indication of a general trend of reduced respiration percentages at the temperature optimum of bacterial growth. Only on 12 September for amino acids, on 14 January for both amino acids and monosaccharides and on 25 March for amino acids did the respiration percentage show a distinct minimum at the optimum temperature of bacterial growth.

\section{DISCUSSION}

Our results indicate that bacterioplankton growth at 1, 6 and $10 \mathrm{~m}$ usually was well adapted to ambient temperatures during most of the growing season. This was shown by the fact that the temperature optimum, or when 2 optima occurred the lower one, agreed with the in situ temperature within $5^{\circ} \mathrm{C}$. We interpret the occurrence of 2 optima as an indication of 2 bacterial subpopulations with different temperature preferences from which one was well adapted to the ambient temperature and thus most relevant for bacterioplankton growth and substrate turnover under in situ conditions (see below). At 20 and $50 \mathrm{~m}$ bacterioplankton growth usually was not well adapted to the fairly low ambient temperatures. Hence, temperature proved to be important in controlling bacterioplankton growth in the upper and lower water column but in 2 different ways. In the upper water column during the growing season the varying temperature led to the establishment of an adapted bacterial community or subpopulation but had a minor effect in directly controlling bacterial growth. In the lower and permanently cold, i.e. $<9^{\circ} \mathrm{C}$, part of the water column, temperature usually directly controlled bacterial growth. This dual temperature effect is also shown by the significant correlation between the in situ temperature and both the rates of BPP-C and BCM at in situ and at optimum temperature, which, however, explained at most $65 \%$ of the variability of these rates (Table 1). Hence, there is room for other controlling factors such as resources (see below).

Other studies have also shown that temperature can be important in controlling bacterioplankton growth. In one approach positive correlations were established between ambient growth or production rates of bacterioplankton at in situ temperatures (White et al. 1991, Morris \& Lewis 1992, Hoch \& Kirchman 1993, Shiah \& Ducklow 1994a, Coveney \& Wetzel 1995, Tibbles 1997). In a

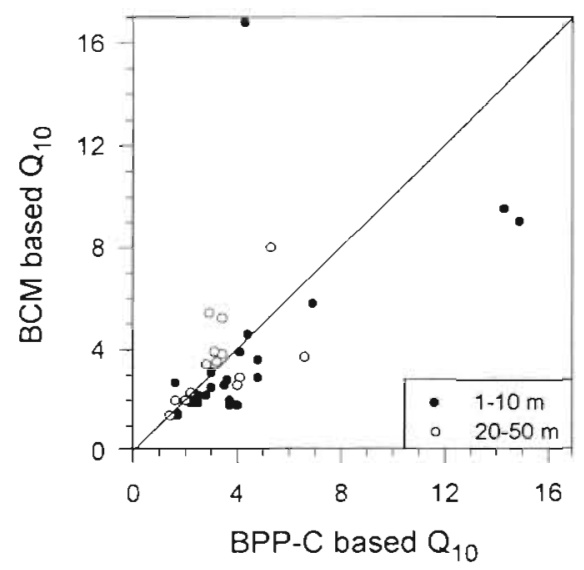

Fig. 6. Scatter plot of $Q_{10}$ values of protein-based bacterial carbon production (BPP-C) and bacterial cell multiplication (BCM) in Lake Constance 
12 September 1996
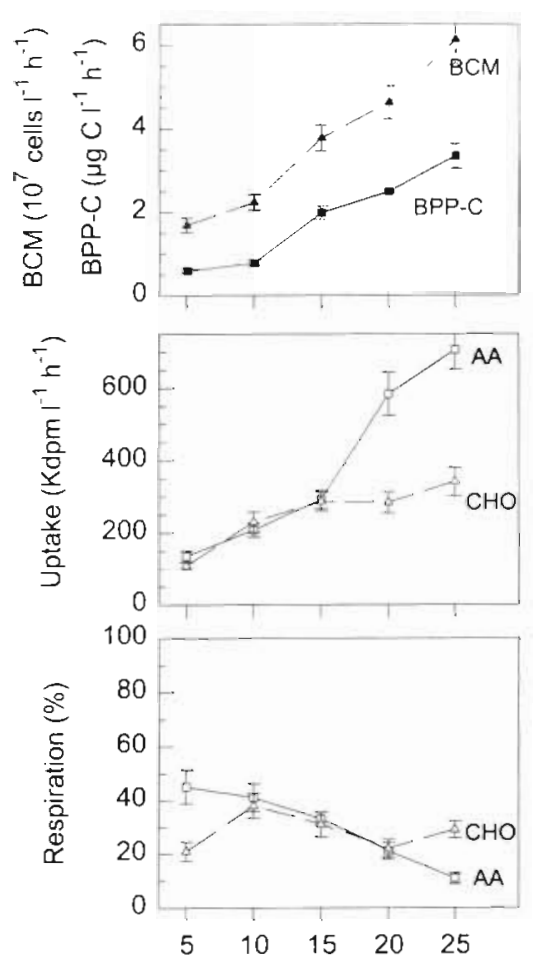

19 September 1996
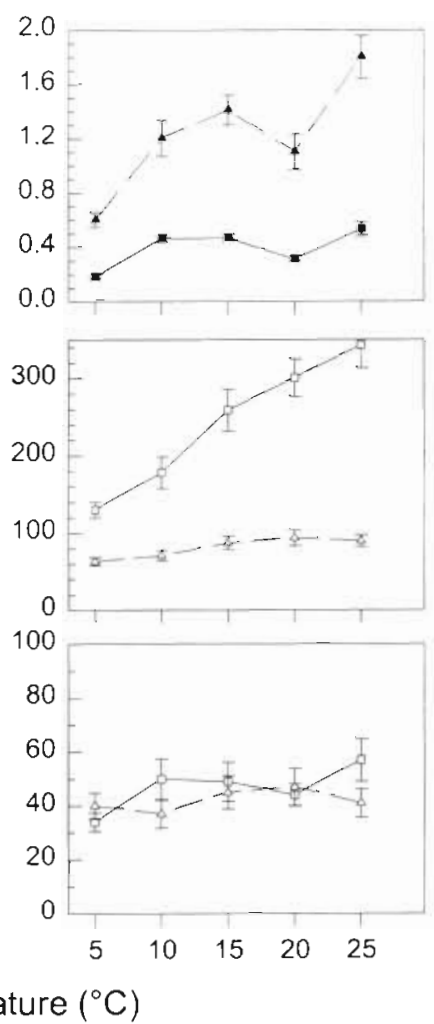

Fig. 7. Protein-based bacterial carbon production (BPP-C) and bacterial cell multiplication (BCM), gross uptake and respiration (\% of gross uptake) of dissolved free amino acids (AA) and monosaccharides $(\mathrm{CHO}) \pm$ standard deviation on 12 and 19 September 1996 at $0 \mathrm{~m}$ in Lake Constance cross-system overview White et al. (1991) found that the effect of temperature on bacterioplankton growth is most pronounced in estuarine environments, followed by marine systems and freshwater lakes. This finding is consistent with observations in the Delaware estuary on the Atlantic coast of the USA that the effect of temperature on bacterial growth was most pronounced in the upper estuary whereas downstream and towards the mouth into the Atlantic temperature had a smaller effect on bacterial growth (Hoch \& Kirchman 1993).

Various studies on temperature shift-up experiments have provided direct evidence of temperature control of bacterioplankton growth. The pioneering work of Sieburth (1967), on the basis of growth characteristics of bacterial isolates, demonstrated that the temperature adaptation of bacterial communities in Narragansett Bay, Rhode Island, USA, varied seasonally but lagged behind the amplitude of the in situ temperature. In situ and optimum temperatures matched only from June to September. In a small eutrophic lake, Lovell \& Konopka (1985) found that between May and
October bacteria were only well adapted to the ambient temperature in the epilimnion in July whereas at other times and in the metaand hypolimnion temperature strongly limited bacterial growth. Felip et al. (1996) in one experiment in a small lake in winter showed that the optimum temperature for bacterial growth was $16^{\circ} \mathrm{C}$ but a second subpopulation had an optimum at the ambient temperature of $4^{\circ} \mathrm{C}$. Autio (1992) found that in the Baltic Sea the in situ and optimum temperature of bacterioplankton growth varied considerably from May to August, but only at the end of July was bacterial growth well adapted to the in situ temperature. Li \& Dickie (1987) found that in the Bedford Basin. Nova Scotia, the optimum temperature of bacterioplankton growth varied seasonally but remained always substantially above the in situ temperature. Studies in the Chesapeake Bay (Shiah \& Ducklow 1994b, 1997) and the subarctic Pacific (Kirchman et al. 1993) showed that the ambient bacterial communities were not well adapted to the in situ temperatures because the optimum temperatures were much higher. On the other hand, studies in the Gerlach Strait of the Southern Ocean (Pakulski et al. 1996) and in the Benguela upwelling (Tibbles 1997) found that bacteria were well adapted to the ambient temperatures of 12 and $0^{\circ} \mathrm{C}$, respectively, even though the highest temperature tested in the Gerlach Strait experiments was only $1^{\circ} \mathrm{C}$. Another recent study reports that bacterioplankton growth was well adapted to ambient temperatures in the Antarctic circumpolar current and the marginal ice zone but not at the Polar Front (Simon et al. 1999)

The available information indicates that in most environments bacterioplankton growth is not well adapted to the ambient temperature or only for short periods of time, mainly in summer. Therefore, it appears remarkable that the bacterioplankton in the upper water column of Lake Constance usually is well adapted to the ambient temperature throughout the growing season. In estuarine and many marine environments and also in small lakes a more or less continuous mixing and exchange of various water masses and the seeding of allochthonous bacterial communjties seem to prevent the establishment of bacterial communities that are well temperature-adapted. Only lakes with a pronounced pelagic zone and a long water retention time and marine systems with constant environmental conditions not affected by the advection of foreign water masses appear to provide the constant conditions for the establishment of bacterial popula- 

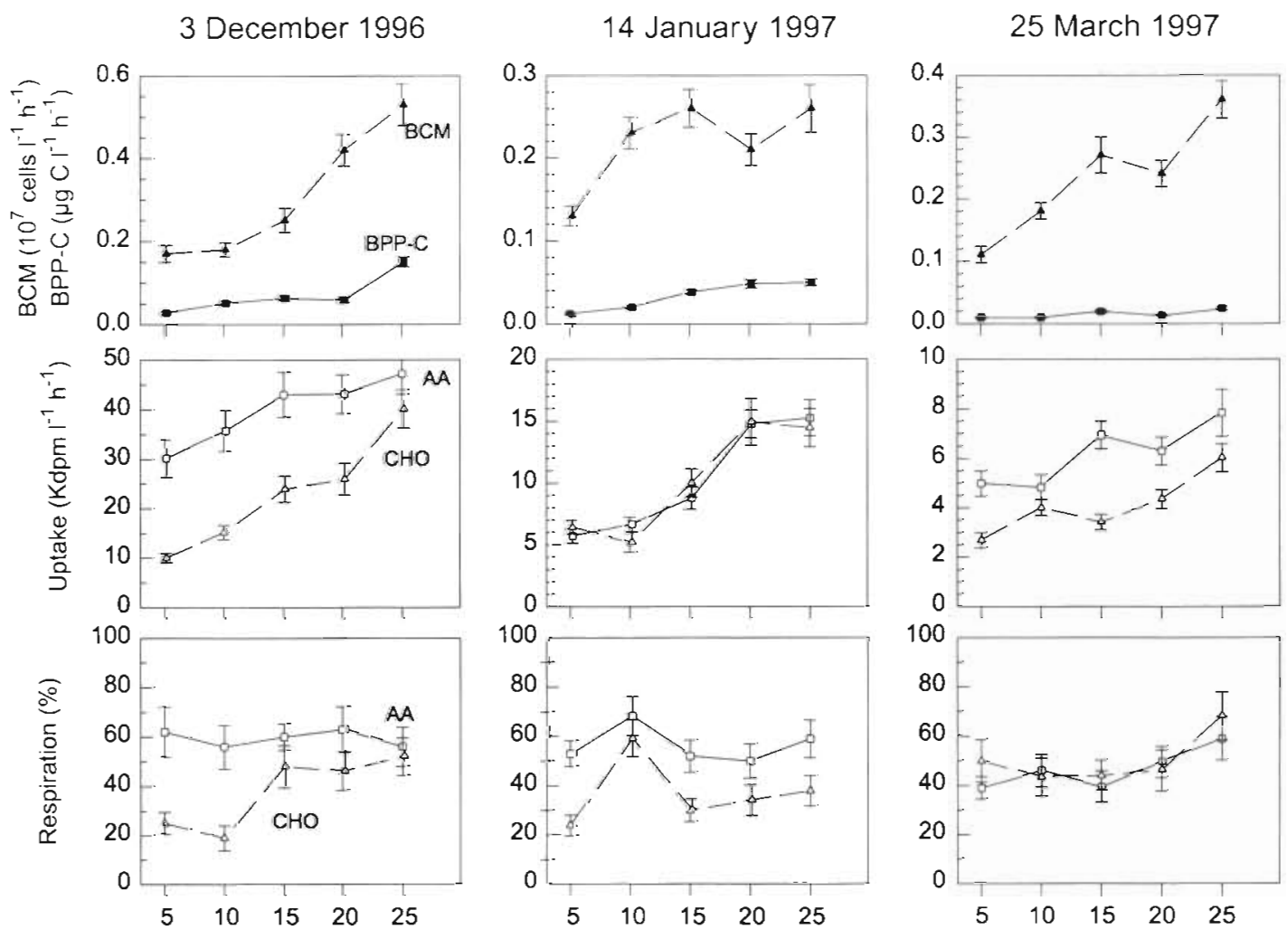

Temperature $\left({ }^{\circ} \mathrm{C}\right)$

Fig. 8. Protein-based bacterial carbon production (BPP-C) and bacterial cell multiplication (BCM), gross uptake and respiration (\% of gross uptake) of dissolved free amino acids (AA) and monosaccharides (CHO) \pm standard deviation on 3 December 1996 and 14 January and 25 March 1997 in Lake Constance. Sampling depths were $1 \mathrm{~m}$ on 3 December and 14 January, and $10 \mathrm{~m}$ on 25 March

tions well adapted to the ambient temperature. We hypothesize that only in these types of aquatic ecosystems can the recycling of dissolved organic matter through the microbial loop into the food web be optimized as a function of temperature with respect to biomass production and respiration (growth yield, but see below). The quality of the substrates utilized, however, is another important factor affecting the growth yield (Kristiansen et al. 1992, Middelboe \& Søndergaard 1993).

We assume that the occurrence of 2 temperature optima in a temperature shift-up experiment was an indication of the existence of 2 bacterial subpopulations with different temperature preferences. One subpopulation was well adapted to and active at the ambient temperature and the other one with a higher temperature optimum can be considered as a seed for higher temperature conditions but does not dominate the activity at the ambient conditions. We do not have direct evidence for the existence of 2 subpopulations. However, to our knowledge, there is no report of biphasic temperature adaptation curves of bacterial pure cultures. Hence it is improbable that homogenous bacter- ial populations with 2 temperature optima exist. In support of this assumption Simon et al. (1999) showed that at the Polar Front in the Southern Ocean, in the Antarctic circumpolar current and in the marginal ice zone bacterial communities with different temperature preferences exhibited pronounced differences in their structural composition as demonstrated by in situ hybridization with fluorescent rRNA-specific oligonucleotide probes. Whereas in the Antarctic circumpolar current and the marginal ice zone bacteria of the $C y$ tophaga/Flavobacterium cluster dominated with 40 and $72 \%$ of the DAPI-stainable bacteria, this group constituted only 19 to $24 \%$ at the Polar Front.

The temperature response of thymidine-based rates of BCM and leucine-based rates of BPP-C generally agreed well. An interesting finding, however, was that the $Q_{10}$ values of rates of BCM and BPP-C exhibited systematic differences. At 1,6 and $10 \mathrm{~m}, Q_{10}$ values of rates of BPP-C were higher than those of $B C M$, except in a few cases in winter, whereas at 20 and $50 \mathrm{~m}, Q_{10}$ values of rates of $\mathrm{BCM}$ in most cases were higher than those of BPP-C. This observation implies that in the upper water column rates of BPP-C increased rela- 
tively more with temperature than rates of $\mathrm{BCM}$. In contrast, in the lower part of the water column rates of $\mathrm{BCM}$ increased relatively more with temperature than rates of BPP-C. Tibbles (1997) and Shiah \& Ducklow (1994b) also found that leucine incorporation (equivalent to BPP-C) increased more with temperature than thymidine incorporation (equivalent to BCM). In accordance to our data, Shiah \& Ducklow (1997) report that in an estuary at temperatures below $20^{\circ} \mathrm{C}$ thymidine incorporation increased with temperature more than that of leucine whereas at an ambient temperature of more than $20^{\circ} \mathrm{C}$ the opposite was true. These comparisons suggest that protein synthesis and DNA replication are controlled differently by temperature. Protein synthesis appears to be favored over cell multiplication at higher temperatures, which leads to larger cells, whereas the opposite is true in colder conditions, leading to relatively smaller cells.

Temperature control of bacterioplankton growth cannot be considered without taking resource limitation into account. If temperature directly controls bacterial growth, bacteria will consume more substrates at higher temperature, thus enhancing the turnover of dissolved organic matter and inorganic nutrients such as $\mathrm{P}$ and $\mathrm{N}$. If the bacterioplankton community is well temperature-adapted, resources directly control bacterial growth within a certain temperature range above which substrate utilization is constant or even reduced. However, in any case bacterial biomass production will be limited as a function of available nutrients relative to the requirements for growth, i.e. biosynthesis and respiration. Recently it has been shown in various studies that growth of heterotrophic bacterioplankton in lakes and the Baltic Sea is mostly limited by $\mathrm{P}$ or colimited by P+C (Morris \& Lewis 1992, Zweifel et al. 1993, Coveney \& Wetzel 1995, Schweitzer \& Simon 1995) whereas in the marine environment growth of heterotrophic bacterioplankton appears more limited by $N$ and $C$ (Kirchman 1990). In studies with facultatively psychrophilic and mesophilic bacterial isolates Wiebe et al. $(1992,1993)$ found that growth at temperatures $\leq 10^{\circ} \mathrm{C}$ was substantially enhanced when substrate concentrations were increased by a factor of 1000 or more whereas at the optimum temperature this was not the case. This observation suggests that substrate utilization at low temperatures and low substrate concentrations is less effective than at high concentrations far exceeding the in situ concentrations, implying that the growth efficiency is reduced under these conditions. Possibly, more energy is required when enzymes function far below their optimum temperature. In fact, Harder \& Veldkamp (1971) reported that obligately psychrophilic bacteria grew faster than facultatively psychrophilic bacteria at $4^{\circ} \mathrm{C}$ both at low and high concentrations of the limiting substrate, indicat- ing that the former were able to optimize substrate utilization at the low temperature. In studies with mixed bacterial communities Felip et al. (1996) and Shiah \& Ducklow (1994b) did not find enhanced growth at high substrate concentrations and temperatures below $10^{\circ} \mathrm{C}$. Because adaptation of bacterioplankton growth to temperature means an optimization with respect to growth rates, one should expect a most efficient utilization of substrates for biosynthetic requirements at the optimum growth temperature.

In the experiments on uptake and respiration of amino acids and monosaccharides, which are the most important substrates for growth of heterotrophic bacterioplankton in Lake Constance (Schweitzer \& Simon. 1995, Hanisch et al. 1996, Simon et al. 1998), we found some, but no consistent, evidence that substrate utilization is optimized at the temperature optimum of bacterial growth. Respiration percentages of amino acids exhibited distinct minima at optimum temperatures on 12 September, 14 January and 25 March, whereas those of monosaccharides had a distinct minimum only on 14 January (Figs. 7 \& 8). There was, however, no general trend towards higher respiration percentages at low temperature nor for preferential utilization of monosaccharides as the energy source. In 3 out of 5 experiments, respiration percentages of amino acids and monosaccharides were fairly similar, whereas in 2 experiments amino acids were respired to even higher degrees than monosaccharides. One difficulty in our experiments was that in 3 out if 5 experiments 2 bacterial communities with different temperature optima were present, overshadowing a clear-cut response of one population to substrate utilization with increasing temperature. However, even a homogenous bacterial population with respect to temperature adaptation consists of an unknown number of bacterial species with presumably different substrate preferences and affinities, making it difficult to get consistent results of substrate utilization and respiration at various temperatures.

In summary, our results showed that the growth of bacterioplankton in Lake Constance is usually well adapted to the ambient temperature in the upper water column, whereas in the lower water column temperature directly limits growth. The biphasic temperature response curves are strong indications of 2 existing bacterial subpopulations with different temperature preferences. In some cases utilization of amino acids and monosaccharides was optimized, i.e. respiration minimized, at the optimum temperature of bacterial growth, whereas in other cases no such optimization was detected. Hence, our results provided some, but no general, support for the hypothesis that utilization of substrates is optimized at the optimum growth temperature. 
Acknowledgements. The expeliments on uptake and respiration of amino acids and monosaccharides on 12 and 19 September 1996 were carried out as part of a student course by J. Benoit, L. Lehner, J. Lichtner, and M. Pfeiffer. We thank an anonymous reviewer for helpful suggestions on an earlier version of this publication. This work was supported by the Special Collaborative Program 'Cycling of Matter in Lake Constance' (SFB 248) funded by the Deutsche Forschungsgemeinschaft.

\section{LITERATURE CITED}

Autio R (1992) Temperature regulation of brackish water bacterioplankton. Arch Hydrobiol Beih Ergebn Limnol 37: 253-263

Chin-Leo G, Kirchman DL (1988) Estimating bacterial production in marine waters from the simultaneous incorporation of thymidine and leucine. Appl Environ Microbiol 54:1934-1939

Coveney MF, Wetzel RG (1992) Effects of nutrients on specific growth rate of bacterioplankton in oligotrophic lake water cultures. Appl Environ Microbiol 58:150-156

Coveney MF, Wetzel RG (1995) Biomass, production, and specific growth rate of bacterioplankton and coupling to primary production in an oligotrophic lake. Limnol Oceanogr 40:1187-1200

Felip M, Pace ML, Cole JJ (1996) Regulation of planktonic bacterial growth rates: the effects of temperature and resources. Microb Ecol 31:15-28

Fuhrman JA, Azam F (1980) Bacterioplankton secondary production estimates for coastal waters of British Columbia, Antarctica, and California. Appl Environ Microbiol 39: $1085-1095$

Gaedke U, Straile D (1994) Seasonal changes of the quantitative importance of protozoans in a large lake. An ecosystem approach using mass-balanced carbon flow diagrams Mar Microb Food Webs 8:163-188

Hanisch K, Schweitzer B, Simon M (1996) Utilization of dissolved carbohydrates by planktonic bacteria in a mesotrophic lake. Microb Ecol 31:41-55

Harder W, Veldkamp H (1971) Competition of marine psychrophilic bacteria at low temperatures. Antonie van Leeuwenhoek 37:51-63

Hobbie JE, Crawford CC (1969) Respiration corrections for bacterial uptake of dissolved organic compounds in natural waters. Limnol Oceanogr 14:528-532

Hoch MP, Kirchman DL (1993) Seasonal and interannual variability in bacterial production and biomass in a temperate estuary. Mar Ecol Prog Ser 98:283-295

Jørgensen NOG, Kroer N, Coffin RB, Yuang XH, Lee C (1993) Dissolved free amino acids, combined amino acids, and DNA as sources of carbon and nitrogen to marine bacteria. Mar Ecol Prog Ser 98:135-148

Kirchman DL (1990) Limitation of bacterial growth by dissolved organic matter in the subarctic Pacific. Mar Ecol Prog Ser 62:47-54

Kirchman DL, K'nees E, Hodson RE (1985) Leucine incorporation and its potential as a measure of protein synthesis by bacteria in natural systems. Appl Environ Microbiol 49:599-607

Kirchman DL, Keil RG, Simon M, Welschmeyer NA (1993) Biomass and production of heterotrophic bacterioplankton in the oceanic subarctic Pacific. Deep-Sea Res 40:967-988

Kristiansen K, Nielsen H, Riemann B, Fuhrman JA (1992) Growth efficiencies of freshwater bacterioplankton. Microb Ecol 24:145-160

Kroer N, Jørgensen NOG, Coffin RB (1994) Utilization of dissolved nitrogen by heterotrophic bacterioplankton: a comparison of three ecosystems. Appl Environ Microbiol 60:4116-4123

Li WKW, Dickie PM (1987) Temperature characteristics of photosynthetic and heterotrophic activities: seasonal variations in temperate microbial plankton. Appl Environ Microbiol 53:2282-2295

Lovell CR, Konopka A (1985) The effects of temperature on bacterial production in a dimictic eutrophic lake. FEMS Microbiol Ecol 31:135-140

Middelboe M, Borch NH, Kirchman DL (1995) Bacterial utilization of dissolved free amino acids, dissolved combined amino acids and ammonium in the Delaware Bay estuary: effects of carbon and nitrogen limitation. Mar Ecol Prog Ser 128:109-120

Middelboe M, Søndergaard M (1993) Bacterioplankton growth yield: seasonal variation and coupling to substrate lability and $\beta$-glucosidase activity. Appl Environ Microbiol 59:3916-3921

Morris DP, Lewis WR (1992) Nutrient limitation of bacterioplankton growth in Lake Dillon, Colorado. Limnol Oceanogr 37:1179-1192

Pakulski JD, Coffin RB, Kelley CA, Holder SL, Downer R, Aas P, Lyons MM, Jeffrey WH (1996) Iron stimulation of antarctic bacteria. Nature 383:133-134

Rich J, Ducklow HW, Kirchman DL (1996) Concentrations and uptake of neutral monosaccharides along $140^{\circ} \mathrm{W}$ in the equatorial Pacific: contribution of glucose to heterotrophic bacterial activity and the DOM-flux. Limnol Oceanogr 41: $595-604$

Rivkin RB, Anderson MR, Lajzerovicz C (1996) Microbial processes in cold oceans. I. Relationship between temperature and bacterial growth rate. Aquat Microb Ecol 10:243-254

Rosenstock B, Simon M (1993) Utilization of dissolved combined and free amino acids by planktonic bacteria in Lake Constance. Limnol Oceanogr 38:1521-1531

Schweitzer B, Simon M (1995) Limiting nutrients for bacterioplankton growth in a mesotrophic temperate large lake Microb Ecol 30:89-104

Sherr EB, Sherr BF (1996) Temporal offset in oceanic production and respiration processes implied by seasonal changes in atmospheric oxygen: the role of heterotrophic microbes. Aquat Microb Ecol 11:91-100

Shiah FK, Ducklow HW (1994a) Temperature regulation of heterotrophic bacterioplankton abundance, production, and specific growth rate in Chesapeake Bay. Limnol Oceanogr 39: 1243-1258

Shiah FK, Ducklow HW (1994b) Temperature and substrate regulation of bacterial abundance, production and specific growth rate in Chesapeake Bay, USA. Mar Ecol Prog Ser 103:297-308

Shiah FK, Ducklow HW (1997) Bacterioplankton growth response to temperature and chlorophyll variations in estuaries measured by thymidine:leucine incorporation ratio. Aquat Microb Ecol 13:151-159

Sieburth JMcN (1967) Seasonal selection of estuarine bacteria by water temperature. J Exp Mar Biol Ecol 1:98-121

Simon M, Azam F (1989) Protein content and protein synthesis rates of planktonic marine bacteria. Mar Ecol Prog Ser 51:201-213

Simon M, Rosenstock B (1992) Carbon and nitrogen sources of planktonic bacteria in Lake Constance studied by the composition and isotope dilution of intracellular amino acids. Limnol Oceanogr 37:1496-1511

Simon M, Bunte C, Schulz M, Weiss M, Wünsch C (1998) Bacterioplankton dynamics in Lake Constance (Bodensee): substrate utilization, growth control, and long-term trends. Arch Hydrobiol Spec Ser Adv Limnol 53:193-219 
Simon M, Glöckner FO, Amann R (1999) Different community structure and temperature adaption of heterotrophic picoplankton in various regions of the Southern Ocean. Aquat Microb Ecol (in press)

Tibbles BJ (1997) Effects of temperature on the relative incorporation of leucine and thymidine by bacterioplankton and bacterial isolates. Aquat Microb Ecol 11:239-250

Weisse T, Müller H (1998) Planktonic protozoa and the microbial food web in Lake Constance. Arch Hydrobiol Spec Ser Adv Limnol 53:221-251

White PA, Kalff J, Rasmussen B, Gasol JM (1991) The effect of temperature and algal biomass on bacterial production.

Editorial responsibility: Karel Simek,

Ceské Budějovice, Czech Republic and specific growth rate in freshwater and marine habitats. Microb Ecol 21:99-118

Wiebe WJ, Sheldon WM Jr, Pomeroy LR (1992) Bacterial growth in the cold: evidence for an enhanced substrate requirement. Appl Environ Microbiol 58:359-364

Wiebe WJ. Sheldon WM Jr, Pomeroy LR (1993) Evidence for enhanced substrate requirement by marine mesophilic bacterial isolates at minimum growth temperature. Microb Ecol 25:151-159

Zweifel UL, Norrman B, Hagström $\AA$ (1993) Consumption of dissolved organic carbon by marine bacteria and demand for inorganic nutrients. Mar Ecol Prog Ser 101:23-32

Submitted: December 23, 1997; Accepted: May 25, 1998 Proofs received from author(s): November 18, 1998 